\title{
Geospatial analysis of urban sprawl in Ile-Ife city, Nigeria
}

\author{
Joseph Oloukoi ${ }^{1}$, Raphael O. Oyinloye ${ }^{2}$, Hubert Yadjemi ${ }^{3}$
}

1. Department of Cartography, oloukoi@ rectas.org, Regional Centre for Training in Aerospace Surveys (RECTAS), Obafemi Awolowo University Campus, Ile-Ife, Nigeria

2. Department of Photogrammetry and Remote Sensing, oyinloye@ rectas.org, RECTAS

3. Department of Geographic Information Systems, yadjemi@ rectas.org, RECTAS

\section{DOI: http://dx.doi.org/10.4314/sajg.v3i2.2}

\begin{abstract}
This paper assesses the effects of urban expansion of Ile-Ife city and appraises the changes that occurred in the landscape from 1986 to 2009. The study made use of information extracted from Landsat TM 1986, ETM+ 2002 and Ikonos 2009 images. GPS observations of notable points within and around the city were overlaid on the topographic map and on the satellite imageries in order to appraise the changes in the land use and land cover over the period. The land consumption was analyzed using the computed land consumption rate (LCR) and land absorption coefficient (LAC) from 1986 to 2009. The average annual rate of urban expansion of Ile-Ife is 3.5\% which translated to a gain of 2256.7 ha in the surrounding rural areas from 1986 to 2002 and about 1434.7 ha between 2002 and 2009. The land is being transformed as shown by the land consumption rate which progressed from 1.1\% in 1986 to $1.2 \%$ in 2002 and remained stable till 2009. The land absorption coefficient has increased from 0.013 to 0.014, confirming the high demand for land both within the city and in the suburbs.
\end{abstract}

Keywords: Urban Sprawl; Land Consumption Rate; Land Absorption Coefficient, Ile-Ife; Remote Sensing

\section{Introduction}

The United Nations (UN) Population Division projected that by 2030, each of the major regions of the developing world will hold more urban than rural dwellers and by 2050, two-thirds of their inhabitants are likely to live in urban areas (Montgomery, 2008). Between 1900 and 1975, the population of these countries had increased by $40 \%$ and from many demographic indicators, about 60\% will be living in cities or urban centres by 2030 (Amin \& Fazal, 2012; Ahlenius, 2009; Adesina et al., 2003). Africa is projected to experience the most rapid growth, over $70 \%$ faster than in Asia (annual growth of $2.4 \%$ versus $1.4 \%$ in Asia, compared to the global average of $1.3 \%$ and only $0.3 \%$ in many industrialized countries) (UN Population Division, 2007; Ahlenius, 2009). In sub-Saharan Africa, the population is projected to increase from about 770 million to nearly 1.7 billion by 2050 . Thus, many developing countries, especially in sub-Sahara Africa, are experiencing more and more rapid urbanization (United Nations, 2013), which is contributing immensely to urban sprawl in both major and minor cities. 
Urban sprawl is commonly described as the spreading of a city to its suburbs. It is the construction of residential and commercial buildings in the adjoining rural areas or otherwise undeveloped lands at the outskirts of a city (wiseGEEK, 2003). As stated by Tofowomo (2008), a general consensus is that urban sprawl is characterized by an unplanned and uneven pattern of growth, driven by a multitude of processes and leading to inefficient resource utilization. UN-HABITAT (2010) remarked that in many developing countries, urban sprawl encompasses two major and contrasting types of development. The first type is characterized by large peri-urban areas with informal and illegal patterns of land use. In these peri-urban areas, there is a lack of infrastructural facilities and basic services, and there is little or no public transport while access roads are inadequate. The second type of development is a form of "suburban sprawl" in which residential zones for highand middle-income groups and high-valued commercial and retail complexes are well connected by individual rather than public transport. Urban sprawl has gained an increasingly prominent interest with the contentious theme in both public and academic discussions in the last decades (Haase and Nuissl, 2007). Some scholars advocated that urban sprawl process has led to a cohort of environmental problems ranging from social segregation to environmental degradations (Squires, 2002; Burchell, 2002) for which appropriate solutions are still needed regarding the growing concern for sustainability (Ewing, 1997).

The high rate of urbanization has become a worldwide phenomenon and Nigeria is not left out in the prevailing global demographic and spatial flux. It has been observed that urban settlements attract people as they offer better economic opportunities and provide access to basic social needs like water and sanitation, better health care and well-being (Oluwole, 2011). Oyinloye \& Adesina (2011) analyzing the situation in Ibadan city (situated at about $70 \mathrm{~km}$ west of Ile-Ife town), observed that one human phenomenon that has been impacting severely on the environment is urbanization. This is reflected by the quality of life in urban centres as well as the spread of the urban features into rural areas. The authors revealed that the urban infrastructures such as roads/streets, electricity, water supply system and waste management system are depreciating and this has compounded the way the cities are sprawling far beyond the range for which the facilities were planned and projected. Beside the expansion of cities into valuable farmlands, urbanization produces solid wastes, and in many cities in Nigeria, the government is obviously losing the battles against the colonization of human abode by human and industrial wastes (Oyinloye \& Adesina, 2011; Raji, 2001; Faniran, 1994). It is therefore obvious that urban sprawl has negative impact on the infrastructure and sustainability of cities. In most cases, it translates to an increase in the cost of transport, public infrastructure and residential and commercial development. In many places, urban sprawl encourages new developments that cause significant loss of prime farmland. When cities are improperly planned, urban sprawl also adds to environmental degradation (UN-HABITAT, 2010).

Urban Sprawl is viewed from different perspectives depending on the background of the expert. Thus the concept appears controversial in many discussions. This confers upon the term a conceptual vagueness and a negative connotation as observed by Haase \& Nuissl (2007). In order to cover the various contradictions and amalgamations, some scholars have attempted to give it a neutral and concise definition. For example, Galster et al. (2001), define sprawl as a pattern of land use in an urbanized area that exhibits low levels of some combination of eight distinct dimensions: density, continuity, concentration, clustering, centrality, nuclearity, mixed uses and proximity. Chin (2002) 
distinguished four types of definition. The first one refers to urban forms as opposed to the compact city (Song \& Knaap, 2004; Burton, 2002). The second is explained in terms of density, or density gradients (Couch et al., 2005), the third one analyses urban sprawl in terms of land use and land cover changes (Batty et al., 1999) and the fourth definition approaches the concept from the negative impact views (Johnson, 2001). From these definitions, it is clear that there are some other dimensions of urban sprawl that need to be reconsidered most especially the negative impacts as they affect the environment and mankind. Agbola \& Agunbiade (2007) highlighted these consequences in some areas in Lagos where consequent planning process was not anticipated. They concluded that urbanization and its attendant processes are parts of the modernization processes and suggested that its' socio-economic and other deleterious environmental consequences must be curtailed.

This study focuses on Ile-Ife city in Osun state in Nigeria. The contemporary post colonial growth of the city is expressed by more developments which have been translated into spatial forms through residential, institutional, commercial and religious land uses. Ikhuoria (1999), through a qualitative analysis, observed the fragmented aspect of the land use and the uncoordinated high density of the suburban housing schemes. Therefore there is still a need to emphasize the urgency of a framework for urban renewal strategies and policies for the city. This study provides information about this by alerting on the spatio-temporal dynamics of the city based on remote sensing (RS) techniques.

RS and GIS provide tools for advanced spatial monitoring and planning, and also provide a potential means for understanding how urban patterns evolve and change over time (Yu \& $\mathrm{Ng}, 2007$; Herold et al., 2003; Herold et al., 2005). Also, RS and GIS prove to be effective means of extracting and processing spatial data of varied resolutions to obtain the necessary information for monitoring urban growth (Masser, 2001). The acquisition of remotely sensed data facilitates the synoptic analysis of the earth's system function patterning and change at local, regional and global scales. Satellite data are useful in mapping and quantifying the extent of urban area at different temporal intervals since RS and GIS are essentially concerned with spatial and temporal dimensions. Jat et al. (2008) studied the sprawl of Ajmer city, India, over a period of 25 years (1977-2002) using remote sensing and GIS techniques to extract the information related to sprawl, area of impervious surfaces and their spatial and temporal variability. Their results revealed that land development (160.8\%) in Ajmer was more than three times the population growth $(50.1 \%)$ between the study period. Bhatta et al. (2010) carried out urban sprawl measurement from remote sensing data in their study to quantify the sprawl in their study area. They documented and discussed these sprawl measurement techniques along with their merits and demerits. Tewolde and Cabral (2011) carried out the urban sprawl analysis and modeling of Asmara, Eritrea, between 1989 and 2009 and found out that the built-up area of urban Asmara tripled in size between the study period. In their study on the nature and pattern of urban expansion of Patna city during the period 1991 - 2008, Gandhi et al. (2012) identified that the land use change illustrates that the urban expansion is inversely proportional to agricultural land use. Thus the urban area increases with decrease in agricultural land. Therefore, the settlement and commercial areas increased. Also, the study indicates that road and rail transport are solely responsible for the rapid urban development in the town. In addition, GIS based analysis of the pattern of urban expansion over the demographic change and land use modifications also indicate that urban growth of the Patna city has mainly taken place linearly along the major river Ganga. 
In the same vein, this paper analyses the urban sprawl phenomenon in the city and provides effective tools for decision making in sustainable urban land use planning. The objectives are to analyze the various shifts observed in the urban area limits since 1986, and evaluate changes in the land use/land cover with a view to determining the level of urban sprawl using satellite remote sensing data and Geographic Information Systems (GIS) applications.

\section{Materials and Methods}

\subsection{The study area}

The study area is located within latitudes $7^{0} 28^{\prime} \mathrm{N}$ and $7^{0} 46^{\prime} \mathrm{N}$, and longitudes $4^{0} 36^{\prime} \mathrm{E}$ and $4^{0} 56^{\prime} \mathrm{E}$ (figure 1). Ile-Ife is an ancient Yoruba town in south western Nigeria. It is situated at the geographical centre of the Yoruba-speaking states of Nigeria. To her west lies Ibadan, and to the east lies Akure, gateway to the major eastern Yoruba towns. Ile-Ife is about 200km NE of Lagos, which was Nigeria's coastal capital city for over a century (Olupona, 2011). Evidence of the urbanization of Ile-Ife has been said to date back to roughly 500 AD (Mabogunje, 1968). Today, it is one of the prominent towns of Osun state, extending over parts of Ife Central, Ife East and Ife North Local Government areas with a population of 355,341 inhabitants in 2006 (NPC, 2006). The socio-cultural group is the Yoruba ethnic group, one of the largest ethnic groups in Africa (Levison, 1998; Olupona, 2011). Ile-Ife is an agricultural trade centre with the presence of various products such as yam, cassava, maize, orange, kola, cocoa and vegetables etc. Ile-Ife, centre for learning and culture, is the home to one of the largest universities in Nigeria, Obafemi Awolowo University (OAU), and it is about 40km to Osogbo, the Osun state capital. 


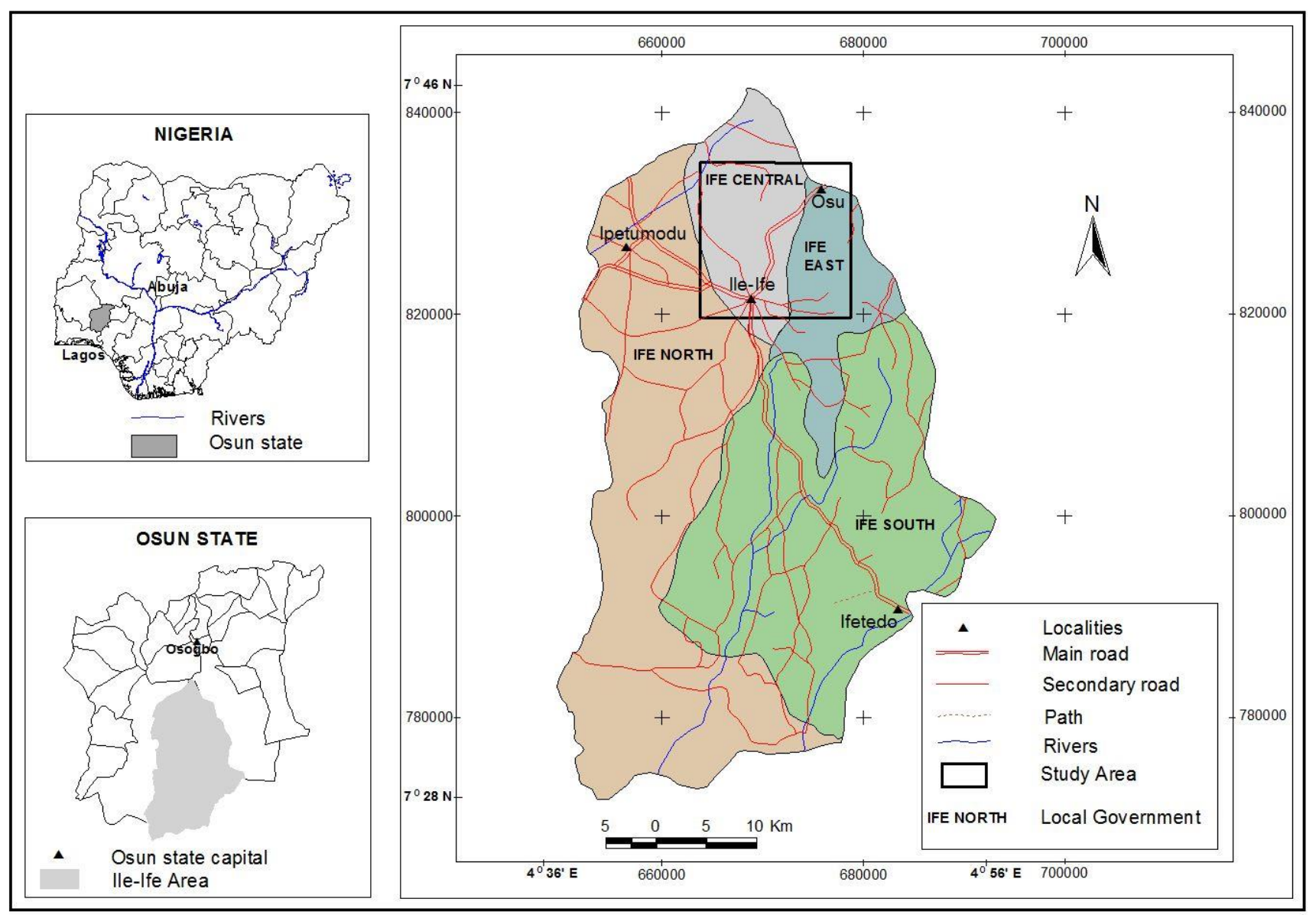

Figure 1: Location of the Study Area - Ile-Ife city, Osun State, Nigeria

\subsection{Data sources}

The primary datasets used for this study are: Landsat TM of 1986, Landsat $\mathrm{ETM}^{+}$of 2002 and Ikonos of 2009 imageries. The GPS observations of points of interest such as new built up areas, farmlands, water bodies, barelands in the study area and socio-economic data were collected. The secondary data used includes topographic maps (sheets Ilesha 243SW, Iwo 242SE, Apomu 262NE and Ondo 263NW) covering Ile-Ife and environs at scale 1:50000 (table 1).

Table 1: Data used and their characteristics

\begin{tabular}{llll}
\hline DATA & DATE & $\begin{array}{l}\text { Scale or } \\
\text { Resolution }\end{array}$ & Usage \\
\hline $\begin{array}{l}\text { Topographic Map sheets Ilesa 243SW, Iwo } \\
\text { 242SE, Apomu 262NE, Ondo 263 NW }\end{array}$ & 1966 & $1: 50000$ & General reference maps \\
\hline $\begin{array}{l}\text { Landsat TM (7 bands) } \\
\text { Landsat ETM+ (7 bands) }\end{array}$ & 1986 & $28.5 \mathrm{~m}$ & $\begin{array}{l}\text { Land Use land cover } \\
\text { information }\end{array}$ \\
Ikonos & 2002 & $28.5 \mathrm{~m}$ & $\begin{array}{l}\text { Built up and other land } \\
\text { use delineation }\end{array}$ \\
\hline GPS observations & 2009 & $1 \mathrm{~m}$ & \\
& $2010-$ & Field work, & $\begin{array}{l}\text { Location of notable areas } \\
\text { in Ife township }\end{array}$ \\
\hline & 2012 & &
\end{tabular}

Apart from the spatial data, we made use of the population data indicated in table 2. 
Table 2: Population data of Ile-Ife city

\begin{tabular}{cc}
\hline Years & Population \\
\hline 1986 & 272297 \\
\hline 2002 & 452023 \\
\hline 2009 & 551794 \\
\hline
\end{tabular}

NB: The population figures were obtained by interpolation using the annual growth rate of $2.8 \%$ (NPC, 2006)

\subsection{Data processing and analysis}

\subsubsection{Satellite image processing and urban sprawl analysis}

The topographic maps were scanned and imported into the ENVI software environment. The maps were then georeferenced, resampled and the submap of the study area was extracted, digitized and incorporated into the database. These maps were all brought to the UTM projection system. Also, the orthorectified satellite images (from source) of Landsat TM and $\mathrm{ETM}^{+}$were similarly imported into ENVI software environment. The sub-scene of the area was extracted and overlaid on the respective images in order to assess the coverage. Bands 4, 3 and 2 were combined (in R G B) and the contrast enhanced using the linear contrast enhancement function of the software. This allows for better visual perception and interpretation of the land use and land cover types on the image.

After satisfactory visual interpretation of the images, the following land use and land cover types were identified and the layers created: built-up area, bareland, farmland, vegetation and water body. The built-up area comprises buildings and other artificial structures. Barelands are exposed land/soil as a result of human activities and exposed rock surfaces within the study area. Farmlands are the areas used for growing crops, cultivated both in wet and dry seasons. The vegetation represents areas covered by trees of different species and sizes, shrubs and woody plants, etc. Water body refers to ground surface water (mainly reservoir, rivers and streams). The visual interpretation was done by means of the interpretation keys such as size, shape, texture, pattern, tone, colour and association of the features. After this, the images (sub-scenes) were classified using the supervised classification techniques. The maximum likelihood algorithm was used in order to compare the various land use features and assess them before drawing meaningful inferences (Shalaby \& Tateishi, 2007; Wu et al., 2006; Yuan et al., 2005). Ground truthing and field survey using Garmin 76CSx GPS receiver were organized to facilitate more accurate interpretation of the satellite imageries, identify and verify important areas and other features as well as the classification accuracy assessment points on the ground and other salient features. Furthermore, the classification results were evaluated by analyzing the confusion matrix, the average overall accuracy and the average reliability. The confusion matrix of 1986 image gave an average accuracy of $88.84 \%$, an average reliability of $89.05 \%$ and the overall accuracy was estimated at $89.70 \%$. For the classification of the 2002 image, the average accuracy is $84.80 \%$, the average reliability $81.86 \%$ and the overall accuracy $85.97 \%$. This shows that the overall Classification both for Landsat TM and $\mathrm{ETM}^{+}$was acceptable and reliable (tables 3 and 4 respectively). 
Table 3: Confusion matrix of the classified Landsat TM 1986 image

\begin{tabular}{lcccccc}
\hline & Vegetation & Bareland & $\begin{array}{l}\text { Built up } \\
\text { area }\end{array}$ & Water body & Farmland & Accuracy \\
\hline Vegetation & 3788 & 10 & 238 & 0 & 28 & 0.93 \\
\hline Bareland & 60 & 2983 & 6 & 76 & 647 & 0.79 \\
\hline Built up area & 92 & 0 & 5615 & 0 & 6 & 0.98 \\
\hline Water body & 22 & 62 & 0 & 3605 & 41 & 0.97 \\
\hline Farmland & 372 & 492 & 19 & 1 & 2969 & 0.77 \\
\hline Reliability & 0.87 & 0.84 & 0.96 & 0.98 & 0.80 & \\
\hline
\end{tabular}

Average Accuracy $=88.84 \%$, Average Reliability $=89.05 \%$, Overall Accuracy $=89.70 \%$

Table 4: Confusion matrix of the classified Landsat $\mathrm{ETM}^{+} 2002$ image

\begin{tabular}{lcccccc}
\hline & Vegetation & Bareland & $\begin{array}{c}\text { Built up } \\
\text { area }\end{array}$ & Water body & Farmland & Accuracy \\
\hline Vegetation & 2886 & 4 & 0 & 0 & 464 & 0.86 \\
\hline Bareland & 2 & 348 & 4 & 10 & 13 & 0.92 \\
\hline Built up area & 0 & 1 & 983 & 0 & 39 & 0.96 \\
\hline Water body & 0 & 6 & 0 & 192 & 1 & 0.96 \\
\hline Farmland & 158 & 31 & 26 & 0 & 243 & 0.53 \\
\hline Reliability & 0.95 & 0.89 & 0.97 & 0.95 & 0.32 & \\
\hline
\end{tabular}

Average Accuracy $=84.80 \%$, Average Reliability $=81.61 \%$, Overall Accuracy $=85.97 \%$

The Ikonos image was on-screen digitized after a thorough visual interpretation aided by some GPS points of the required land use land cover features taken in the field.

The change detection technique comparing the supervised classification results of the multitemporal images giving areal coverage of each theme was used. The annual rate of change was calculated for each LULC theme from 1986 to 2002 and 2002 to 2009 using the following mathematical expression (eq.1) (Schulz et al., 2010; Oloukoi et al., 2011). The variable considered here is the area for each land use and land cover type. The areas were generated directly in ArcGIS 9.2 environment using the spatial analysis function. If $S_{1}$ and $S_{2}$ correspond to the areas of a certain land use and land cover type in years $\mathrm{t}_{1}$ and $\mathrm{t}_{2}$ respectively, the annual rate of the spatial expansion $T$ is calculated as follows:

$$
T=\left(\left(\frac{1}{t_{2}-t_{1}}\right) \times \ln \left(\frac{S_{2}}{S_{1}}\right)\right) * 100
$$

The mathematical expression was used to analyze the urban sprawl by comparing the surface area of the town from 1986 to 2002 and 2002 to 2009.

\subsubsection{Analysis of land consumption and absorption}

In order to improve the understanding of the quantitative changes in the Land use land cover (LULC) in Ile-Ife, this study incorporates the concept of land consumption. As noted by Zubair (2008), land is becoming a scarce resource due to immense agricultural and demographic pressures. Therefore, there is the need to provide information on the rate of consumption of lands per unit population growth and the possibilities for their optimal use for planning in order to meet the increasing demands for basic human needs and welfare. This information also assists in monitoring the 
dynamics of settlement expansion resulting from changing demands of the increasing population. The land consumption considers three aspects (EEA, 1997):

- The expansion of built up area which can be directly measured,

- The absolute extent of land that is subject to exploitation by agriculture, forestry or other economic activities, and

- The over intensive exploitation of land that is used for agriculture and forestry.

The first two aspects were taken into consideration in this study and they are expressed by the Land Consumption Rate (LCR) and the Land Absorption Coefficient (LAC). The land consumption rate measures the compactness which indicates the level of the spatial expansion of a city while the land absorption coefficient measures the amount of changes in consumption of new urban land per unit increase in urban population (Amin \& Fazal, 2012; Olaleye et al., 2012; Zubair, 2008; Jenson \& Cowen, 1999; Olorunfemi, 2001; Yeates \& Garner, 1976).

$$
L C R=\frac{S}{P}
$$

where $\mathrm{S}$ is the areal extent of Ile-Ife town in hectares and $\mathrm{P}$ the population.

$$
L A C=\frac{S_{2}-S_{1}}{P_{2}-P_{1}}
$$

where $S_{1}$ and $S_{2}$ are the areal extents for the early and later years, and $P_{1}$ and $P_{2}$ are population figures for the early and later years respectively.

\section{Results and discussions}

\subsection{Urban sprawl and land cover change}

The limits of the urban areas of Ile-Ife, extracted from the satellite imageries have experienced shifts as the years went by from 1986 to 2009 (figure 3). In 1986, the area it occupied was about 3002.2 ha, which extended to more than 5000 ha in 2002 and more than 6500 ha in 2009.

The annual rate of urban expansion is an average of 3.5\% per year which translated to a gain of 2256.7 ha from 1986 to 2002 and about 1434.7 ha between 2002 and 2009 (table 5). 


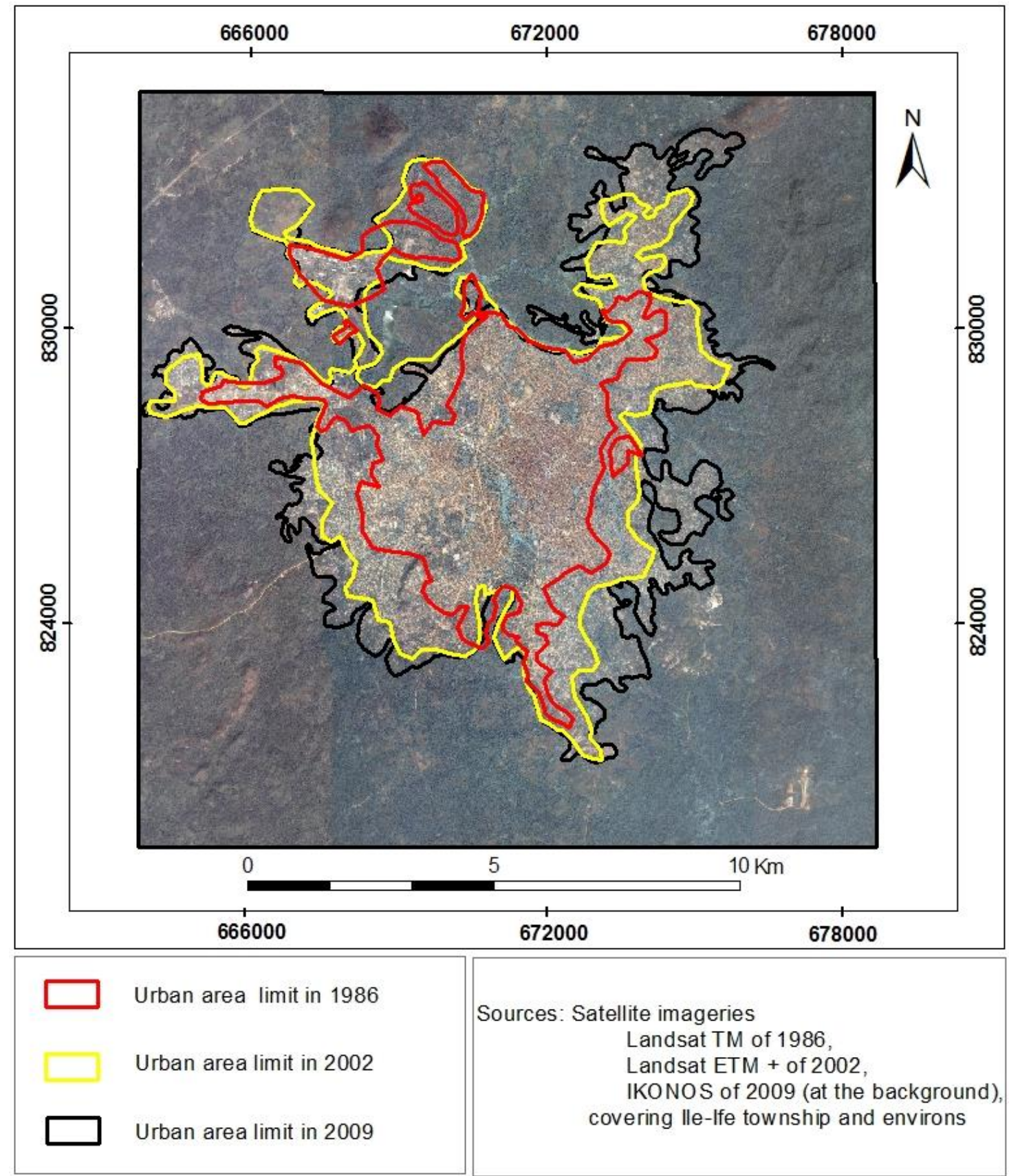

Figure 3: Urban sprawl of Ile-Ife from 1986 to 2009

Table 5: Urban sprawl quantitative analysis

\begin{tabular}{ccccccc}
\hline & 1986 & 2002 & 2009 & $\begin{array}{c}\text { Annual } \\
\text { change (1986-2002) }\end{array}$ & $\begin{array}{c}\text { rate of } \\
\text { chnual rate (2002-2009) }\end{array}$ \\
\hline $\begin{array}{c}\text { Extent of } \\
\text { chrban area } \\
\text { (ha) }\end{array}$ & 3002.2 & 5258.9 & 6693.6 & $3.56 \%$ & $3.5 \%$ \\
\hline
\end{tabular}

The classification and interpretation of the satellite images indicate five classes of land use and land cover (built up area, farmlands, vegetation, barelands and water body) (table 6). 
Table 6: Land use / cover change from 1986 to 2009 in Ile-Ife

\begin{tabular}{lcccccc}
\hline & $\begin{array}{c}\text { Surface Area } \\
\text { in 1986 (ha) }\end{array}$ & $\begin{array}{c}\text { Surface Area } \\
\text { in 2002 (ha) }\end{array}$ & $\begin{array}{c}\text { Surface Area } \\
\text { in 2009 (ha) }\end{array}$ & $\begin{array}{c}\text { Annual Rate } \\
\text { of change } \\
(1986-2002)\end{array}$ & $\begin{array}{c}\text { Annual Rate } \\
\text { of change } \\
(2002-2009)\end{array}$ & $\begin{array}{c}\text { Annual Rate } \\
\text { of change } \\
\text { (average) }\end{array}$ \\
\hline Vegetation & 19299.39 & 13458.79 & 8387.55 & -2.25 & -6.76 & -4.51 \\
\hline Bareland & 647.68 & 325.47 & 557.97 & -4.30 & 7.70 & 1.70 \\
\hline Built-up area & 1966.71 & 5855.24 & 6959.17 & 6.82 & 2.47 & 4.65 \\
\hline Water body & 66.14 & 57.20 & 44.50 & -0.91 & -3.59 & -2.25 \\
\hline Farmland & 916.85 & 3200.09 & 6947.60 & 7.81 & 11.07 & 9.44 \\
\hline Total & $\mathbf{2 2 8 9 6 . 7 8}$ & $\mathbf{2 2 8 9 6 . 7 8}$ & $\mathbf{2 2 8 9 6 . 7 8}$ & & & \\
\hline
\end{tabular}

The total area mapped comprises the core of the town and the suburbs with a total extent of about 22896.78 ha. Over the entire study period, vegetation was the predominant land cover type due to the inclusion of the suburbs in the study area. In 1986, it was dominating the landscape with a proportion of more than $84 \%$. Vegetation, predominant in the suburb areas, declined at the highest average annual rate of $-4.5 \%$ and reduced from $84 \%$ of the study area in 1986 to about $37 \%$ in 2009 (figures 4).

Built up area is the second largest land use and land cover type with a proportion of about $8.6 \%$ in 1986. It increased to $25.6 \%$ in 2002 and more than $30 \%$ in 2009. Built-up includes areas of intensive use with much of the land covered by structures, i.e., residential, scattered buildings, commercial, industrial, educational, governmental, hospital and religious land uses. Analysis shows that about 3888.52 ha of built up area was added between 1986 and 2002 while the area increased by about 1103 ha between 2002 and 2009 (figure 5). 


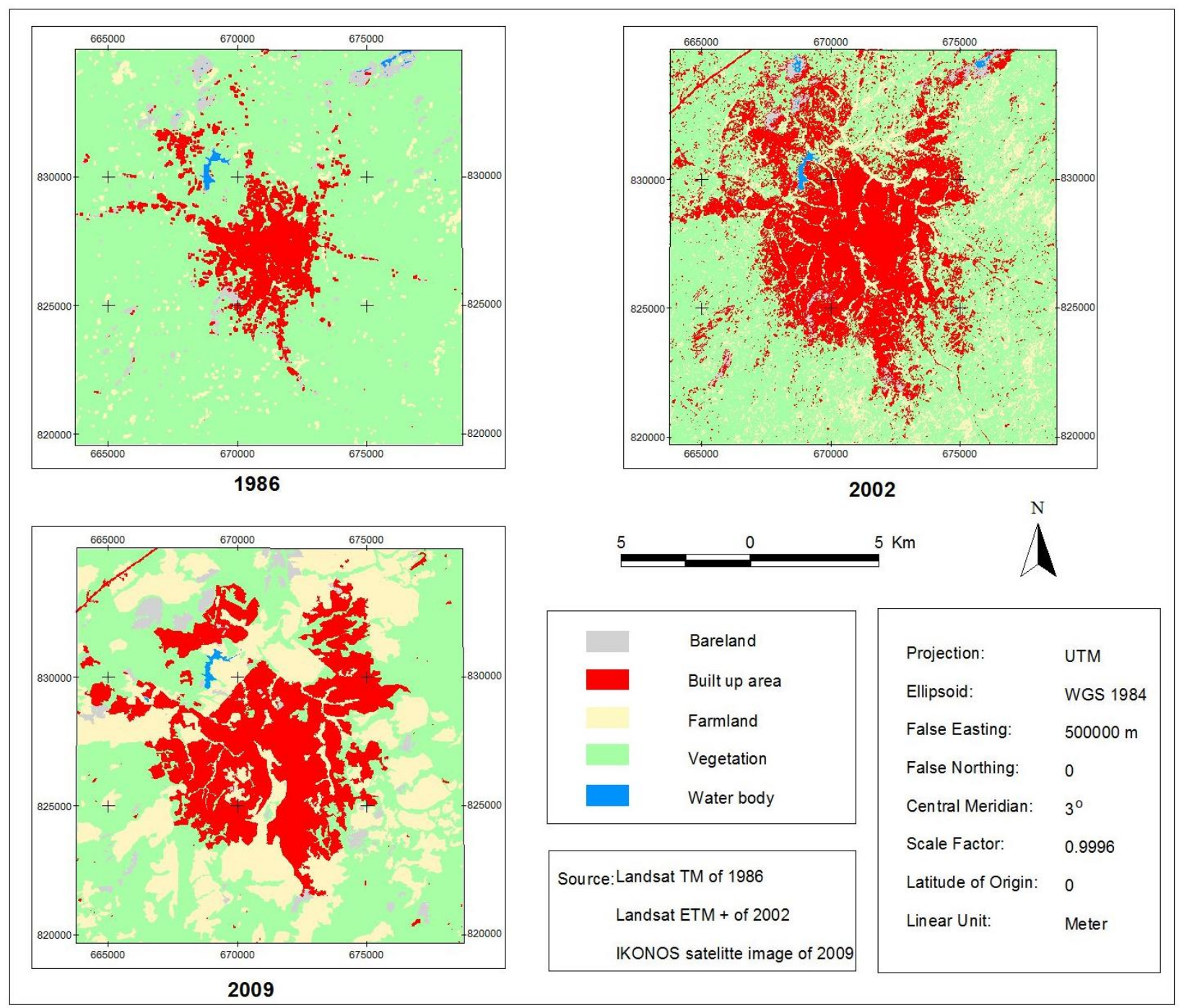

Figure 4: Land use/land cover map of Ile-Ife area 1986, 2002 and 2009

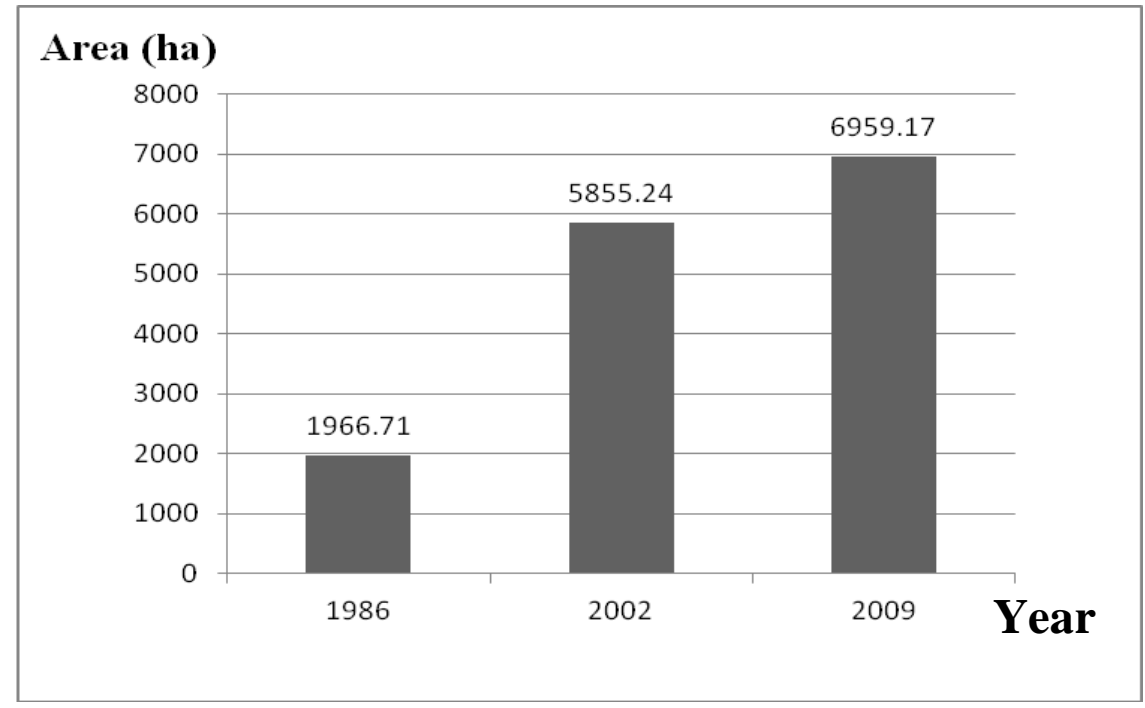

Figure 5: Expansion of the built up area of Ile-Ife city 
This increase in built up area is attributed to the high demand for shelter and other urban infrastructure by the rapidly growing population and the development made in secondary and tertiary sectors. The annual rate of change of built up area is more than $4.6 \%$ indicating a rapid expansion of the city especially towards the eastern, the southern and the western axes of the urban centre (figure 4).

Farmland is the third largest land cover class in the landscape considered. In 1986, the total area under farmland was 916.85 ha (about $4 \%$ of the total area of study), which increased to 3200.09 ha (about $14 \%$ of the total area of study) in 2002 and 6947.59 ha (about $30.3 \%$ of the total area of study) in 2009. Therefore 6030.74 ha of agricultural land have been gained during the period of 23 years in the study area with an average annual growth rate of $9.4 \%$. Farmlands are mainly observed in the surroundings of the town and to some extent along some stream courses and valleys within the town, allowing the development of urban agriculture for growing of vegetable, okra, banana, maize, yam, sugar cane, plantain and even cocoa as well as the construction of fish ponds.

\subsection{Land transformation}

It is observed that land is being transformed as shown by the changes in the state of the land use land cover types under human pressures for socioeconomic activities. This is expressed by the slight increase in the land consumption rate which progressed from $1.1 \%$ in 1986 to $1.2 \%$ in 2002 and remained stable till 2009 (table 7). The compactness of the town, an indication of its spatial expansion, suggests that from 2002 to 2009, the rate at which the town was expanding remained the same. Similarly, the land absorption coefficient has increased confirming the high demand for land both within the city and the suburbs. This coefficient which was 0.13 between 1986 and 2002 slightly increased to 0.14 between 2002 and 2009, indicating that the land is being transformed. It also indicates that the increase in population between 1986 and 2002 is responsible for the increase in urban expansion. The same argument holds for the urban expansion between 2002 and 2009, which affirms the slight increase in the land absorption coefficient during the period.

Table 7: Land Consumption Rate (LCR) and Land Absorption Coefficient (LAC)

\begin{tabular}{lccccc}
\hline & Area & Population & LCR (\%) & Period & LAC \\
\hline & & & & $1986-$ & \\
1986 & 3002.2 & 272297 & 1.1 & 2002 & 0.013 \\
\hline 2002 & 5258.9 & 452023 & 1.2 & $2002-$ & \\
\hline 2009 & 6693.6 & 551794 & 1.2 & & \\
\hline
\end{tabular}

The transformation observed is ascertained by the changes in the land use land cover. For example, the rate of change in the vegetation areas is the highest, which was mainly converted to farmlands within the town (urban agriculture) and also at the surroundings. Furthermore, many of the other land use/ land cover types are being transformed into built up area. For example, alongside the main axes of the town, such as Ibadan road, Ede road, Ilesha road and Ondo road, new structures like petrol stations, shops, churches, schools, hotels and other commercial enterprises are erected and some renovated. 


\subsection{Discussion}

The medium resolution images allow a generalization level during the interpretation process that may not include some detailed features in urban areas because of the size of the pixel and also regarding the dynamics and texture of such areas. This study has focused more on the spatial expansion rather than the patches within the town, which gave the results some credibility with the use of a high resolution image like Ikonos of 2009 to complement the medium resolution images. A similar approach was adopted by Amin \& Fazal (2012) who used a IRS multispectral image with four bands and $23.5 \mathrm{~m}$ resolution and its panchromatic band with $5.8 \mathrm{~m}$ resolution. The methodological approach is also similar to the one used by $\mathrm{Yu} \& \mathrm{Ng}$ (2007) in a study on the spatio-temporal dynamics of urban sprawl along two urban-rural transects in Guangzhou, China, but the study made use of four Landsat TM scenes. Also, by emphasizing the spatio-temporal dynamic of Ile-Ife using multidate satellite imageries, this study is an improvement on the work of Ikhuoria (1999) who analyzed the urban growth of the city using a single satellite image (SPOT-1 of 1986). The concept of urban sprawl needs deep consideration apart from the spatial expansion aspects because it is a multifaceted concept. Beside the spreading outwards of a city and its suburbs to low-density areas, it also includes a high segregation of uses. At the same time, it has been argued that urban sprawl is the root of many environmental problems which have exhibited a negative impact on infrastructure and human well being. However, some authors like Gordon \& Richardson (2001) and Alberti \& Marzluff (2004) recognized that fact but also strongly support the view that the problems of urban sprawl are far outweighed by its benefits in that it enables a growing number of people to live according to their desires. Despite the debate about urban sprawl, this paper has addressed the reality of cities expansion in Nigeria, calling for necessary planning policy as pointed out by Zubair (2008) and Olaleye et al. (2012) in separate studies in Ilorin where the land consumption rate is similar to that of Ile-Ife. However, the causes of the increasing consumption of land as observed by Olorunfemi (1983) in Ilorin and by Tofowomo (2008) in Akure, need a more in-depth consideration.

\section{Conclusion}

It is acknowledged in this paper that Ile-Ife, a city known as the cradle of Yoruba land and Yoruba culture, is experiencing the sprawl phenomenon. Considering a long period of time of twenty three (23) years from 1986 to 2002 in the first instance and from 2002 to 2009 in the second, and with the use of remote sensing satellite imageries supported by field survey data, the research shows that the city is expanding at an average rate of $3.5 \%$ per annum. The paper further discussed the transformation that occurred in land use and land cover noting that a large part of vegetation or bareland areas have been transformed into built up and agricultural land.

Regarding the rapid rate at which the city is growing, coupled with urban land transformation, there is the need for adequate planning strategies to be formulated in order to properly monitor and control the uncoordinated land occupation such as the extension of built up area to flood plains and floodable areas. This planning scheme should also consider a land administration programme at the formulation and implementation stages. 


\section{Acknowledgements}

Appreciation is expressed to the Regional Centre for Training in Aerospace Surveys (RECTAS) for the provision of the satellite imageries.

\section{References}

Adesina, FA, Siyanbola, WO, Okelola, FO, Pelemo, DA, Ojo, LO, \& Adegbulugbe, AO 2003, Potentials of agroforestry for climate change mitigation in Nigeria, some preliminary estimates. Glob. Ecol. Biogeogr. Lett., vol. 8, pp. 163-173.

Agbola, T \& Agunbiade, E M 2007, Urbanization, Slum Development and Security of Tenure: The Challenges of Meeting. Paper presented to the PRIPODE workshop onUrban Population, Development and Environment Dynamics in Developing Countries, Nairobi.

Alberti, M \& Marzluff, J M 2004, Ecological resilience in urban ecosystems: linking urban patterns to human and ecological functions. Urban Ecosyst., vol. 7, no 3, pp. 241-265.

Amin, A \& Fazal, S 2012, Quantification of Land Transformation using Remote Sensing and GIS techniques. American Journal of Geographic Information System, vol. 1, no 2, pp.17-28.

Ahlenius, H 2009, Trends in population, developed and developing countries, 1750-2050 (estimates and projections). UNEP/GRID-Arendal, http://www.grida.no/graphicslib/detail/trends-inpopulation-developed-and-developing-countries-1750-2050-estimates-and-projections_1616 (Accessed on the 04/12/2013)

Batty, M, Xie, Y, \& Sun, Z 1999, The Dynamics of Urban Sprawl. ,. (L. Centre for Advanced Spatial Studies (CASA), Ed.) CASA Working Paper Series, Paper 15.

Bhatta, B, Saraswati, S \& Bandyopadhyay, D 2010, Urban sprawl measurement from remote sensing data, Applied Geography, vol. 30, no. 4, pp. 731-740

Burchell, RW, Lowenstein, G, Dolphin, WR, Galley, CC, Downs, A, Seskin, S, \& Moore, T 2002, Costs of Sprawl-2000. Transportation Cooperative Research Program, Report 74. Washington, D.C.: National Academic Press.

Burton, E 2002, Measuring urban compactness in UK towns and cities. Environ. Plann. B, vol. 29, no. 2, pp 219-250.

Chin, N 2002, Unearthing the roots of urban sprawl: a critical analysis of form, function and methodology. (L. Centre for Advanced Spatial Studies (CASA), Ed.) CASA Working Paper Series, Paper 47.

Couch, C, Karecha, J, Nuissl, H, \& Rink, D 2005, Decline and sprawl: an evolving type of urban development - observed in Liverpool and Leipzig. Eur. Plan. Stud., vol. 13, no.1, pp. 117136.

EEA 1997, The concept of environmental space. . Copenhagen: European Economic Association.

Ewing, R 1997,Counterpoint: is Los-Angeles-style sprawl desirable? J. Am. Plann. Assoc, vol. 63, no 1, pp.107-126.

Faniran, A 1994, Solide waste management . In MO Filani, F O Akintola, \& C O Ikporukpo (eds.), Ibadan region, Ibadan: Rex Charles Publication and Connel Publications, pp. 231-243. 
Galster, G, Hanson, R, Ratcliffe, MR, Wolman, H, Coleman, S, \& Freihage, J 2001, Wrestling sprawl to the ground: defining and measuring an elusive concept, Housing Policy Debate, vol. 12, no 4, pp.681-717.

Gandhi, IS, Madha, SV \& Stalin, M 2012, Study of Urban Sprawl of Patna City Using Remote Sensing and GIS, International Journal of Remote Sensing and GIS, vol. 1, no. 3, pp.144-153

Gordon, P., \& Richardson, HW 2001, The sprawl debate: let markets plan. Publius - J. Federalism, vol.31, no 3, pp 131-149.

Haase, D \& Nuissl, H 2007, Does urban sprawl drive changes in the water balance and policy?: The case of Leipzig (Germany) 1870-2003. Landscape and Urban Planning, vol. 80, no.1-2, pp.113.

Herold, M, Couclelis, H \& Clarke, KC 2005, The role of spatial metrics in the analysis and modeling of urban land use change. Comput. Environ. Urban Syst., vol. 29, pp.369-399.

Herold, M, Goldstein, NC, \& Clark, KC 2003, The spatiotemporal form of urban growth: measurement, analysis and modeling. Remote Sens. Environ., vol. 86, pp. 286-302.

Ikhuoria, IA 1999, SPOT satellite detection and analysis of urban spatial growth regimes in a precolonial African city. GeoCarto International, vol. 4, pp.49-52

Jat, MK, Garg, PK \& Khare, D 2008, Monitoring and modelling of urban sprawl using remote sensing and GIS techniques, International Journal of Applied Earth Observation and Geoinformation, vol. 10 , no. 1 , pp. $26-43$

Jenson, JR \& Cowen, DC 1999, Remote sensing of urban/suburban infrastructure and socio-economic attributes. Photogrammetric Engineering and Remote Sensing, vol. 65, no. 5, pp.611-622.

Johnson, M P 2001, Environmental impacts of urban sprawl: a survey of the literature and proposed research agenda. Environ. Plann. A, vol. 33, no. 4, pp. 717-735.

Levison, D 1998, Ethnic groups worldwide: A ready reference book. Arizona, USA: Greenwood Publishing Group.

Masser, I. 2001. Managing urban future: The role of remote sensing and geographic information systems, Habitat International, vol. 25, pp. 503-512

Mishra, M., Mishra, K., Subudhi, A., and Phil, M., 2011, Urban sprawl mapping and land use change analysis using remote sensing and GIS: Case study of bhubaneswar city, Orissa, Proceedings of the Geo-Spatial World Forum, January 18-21, Hyderabad, India.

Mabogunje, A L 1968, Urbanization in Nigeria. London: University of London.

Montgomery, M R 2008, The urban transformation of the developing world. Science, vol. 319, pp.761-764.

NPC 2006, Population Census of Nigeria final results. Federal Republic of Nigeria, Official Gazette 2009, vol. 96, no 2, pp. 41-42.

Olaleye, JB, Abiodun, OE \& Asonibare, RO 2012, Land-use and land cover analysis of Ilorin

Emirate between 1986 and 2006 using Landsat imageries. African Journal of Environmental

Science and Technology, vol. 6, no. 4, pp.189-198

Olorunfemi JF 2001, Better by far, 51 Inaugural Lecture, publication of the University of Ilorin. $60 \mathrm{p}$

Olorunfemi, JF 1983, Monitoring Urban Land use in Developing Countries: An Aerial Photographic Approach, Environment International, vol. 9, pp. 27-32.

Oloukoi, J, Houssou, SC, \& Oyinloye, RO 2011, Landscape and vegetation fragmentation in the central region of Benin Republic. In O. Salami A. T. and Orimoogunje (eds.), Environmental 
Research and challenges of sustainable development in Nigeria, Ile-Ife: Obafemi Awolowo University Press, pp. 484-499.

Olupona, J 2011, City of 201 Gods. Ilé-Ifè in Time, Space, and the Imagination. University of California Press.

Oluwole, PD 2011, Community Participation and Sustainable Urban Environmental Management in Nigeria: A review. In A. T. Salami, \& O. O. Orimoogunje (eds.), Environmental Research and challenges of sustainable development in Nigeria Ile-Ife: Obafemi Awolowo University Press, pp. 596-610.

Oyinloye, RO, \& Adesina, FA 2011, The Paradoxal Effects of Urbanization in Developing Countries. A case study of solid waste pollution in Ibadan City, Nigeria. In AT. Salami, \& OO Orimoogunje (eds.), Environmental Research and Challenges of Sustainable Development in Nigeria), Ile-Ife: Obafemi Awolowo University Press, pp. 641-679

Raji, O 2001, Waste production and management in Lagos State. Obafemi Awolowo University, Department of Geography. Ile-Ife: Unpublished BSc.

Schulz, JJ, Cayuela, L, Echeverria, C, Salas, J, Man, J, \& Benayas, R 2010, Monitoring land cover change of the dryland forest landscape of Central Chile (1975-2008). Applied Geography, vol. 30, 36-447.

Shalaby, A \& Tateishi, R 2007, Remote sensing and GIS for mapping and monitoring land cover and land-use changes in the Northwestern coastal zone of Egypt. Applied Geography, vol. 27, no.1, pp. 28-41.

Song, Y, \& Knaap, CJ 2004, Measuring urban form: is Portland winning the war on sprawl? J. Am. Plann. Assoc., vol. 70, no. 2, pp.210-225.

Squires, GD 2002, Urban Sprawl: Causes, Consequences and Policy Responses. Washington, D.C.: The Urban Institute Press.

Tewolde, MG \& Cabral, P 2011 Urban Sprawl Analysis and Modeling in Asmara, Eritrea Remote Sensing, vol. 3, no. 10, pp. 2148-2165

Tofowomo, A 2008, The Planning Implications of Urban Sprawl in Akure. 44th ISOCARP Congress, $6 \mathrm{p}$.

United Nations 2013, Population, development and the environment 2013. Retrieved on 05 12, 2013 from http://www.un.org/en/development/desa/population/publications/pdf/development/ pde_wallchart_2013.pdf

UN-HABITAT 2010, Urban trends: urban sprawl now a global problem. Nairobi: United Nations Human Settlements Programme.

United Nations Population Division 2007, World Urbanization Prospects: The 2007 Revision Population Database. Retrieved on 05 12, 2013 from http://www.un.org/esa/population/publications/wup2007/2007WUP_Highlights_web.pdf

wiseGEEK 2003, What is Urban Sprawl? Retrieved 06 04, 2013, from wiseGEEK: http://www.wisegeek.com/what-is-urban-sprawl.htm

Wu, Q, Li, H, Wang, R, Paulussen, J, Hec, Y, Wang, M, Wang, Z 2006, Monitoring and predicting land use change in Beijing using remote sensing and GIS. Landscape and Urban Planning, vol. 78, no. 4, pp. 322-333.

Yeates, M \& Garner, B 1976, The North American City. New York: Harper and Row Publication. 
$\mathrm{Yu}, \mathrm{XJ}, \& \mathrm{Ng}, \mathrm{CN}$ 2007, Spatial and temporal dynamics of urban sprawl along two urban-rural transects: A case study of Guangzhou, China. Landscape and Urban Planning, vol. 79, no. 1, pp. 96-109.

Yuan, F, Sawaya, KE, Loeffelholz, BC, \& Bauer, ME 2005, Land cover classification and change analysis of the twin cities (Minnesota) metropolitan area by multitemporal landsat remote sensing. Remote Sensing of Environment, vol. 98, no. 2-3, pp. 317-328.

Zubair, AO 2008, Monitoring the growth of settlements in Ilorin, Nigeria. In AARSE (Ed), Conference proceedings on the 7th AARSE International Conference on Earth Observation and Ceoinformation for governance in Africa, Accra. pp. 380-391 